\title{
Effect of Dietary Natural Phytochemicals on Sex-reversal, Growth Performance, Feed Utilization and Body Composition of Nile Tilapia (Oreochromis niloticus) Fry
}

\section{Eglal Ali Omar ${ }^{1}$, Mokhtar Ibrahim Yousef ${ }^{2}$, Tarek Mohamed Srour ${ }^{1}$, Abdallah Tag-Eldein Mansour ${ }^{1 *}$}

1'Department of Animal and Fish Production, Faculty of Agriculture, Alexandria University, Egypt.

${ }^{2}$ Department of Environmental Studies, Institute of Graduate Studies and Research, Alexandria University, Egypt.

*Corresponding author address: 22 Tag El-Roasa St. Saba Basha, Boulkly, P.O. Box 21531, Alexandria, Egypt. Tel.: +2 03 5830605, Mobile: +201113711946; Fax: +2 03 5832008, E-mail: a taag@yahoo.com

\begin{abstract}
: a feeding study was conducted to evaluate the effect of different natural phytochemicals as alternative sex-reversal agents instead of 17a-methyl testosterone (MT). Newly hatched Nile tilapia (Oreochromis niloticus) fry were treated with MT (60 mg/kg), ginseng extract (GE; 0.2 or $0.4 \mathrm{~g} / \mathrm{kg}$ ), Tribulus terrestris extract (TTE; 0.6 or $1.2 \mathrm{~g} / \mathrm{kg}$ ) and date palm pollen (DPP; 3 or $6 \mathrm{~g} / \mathrm{kg}$ ) in diet. The treatment period lasted for 28 days for MT and 84 days for other phytochemicals. The results showed that the maximum male percentage recorded with MT (92.30\%), followed by TTE (1.2 g/kg; 64.48\%), TTE (0.6 g/kg; $57.76 \%)$ and DPP (6 g/kg; 56.67\%), while the male percentage of the control was $48.36 \%$. All studied treatments showed normal survival rates along the experimental period, which proves that the used phytochemicals are nontoxic. Fish treated with phytochemicals exhibited successful growth acceleration compared to the control group especially with TTE treatments. The same manner was observed with feed conversion ratio. Carcass composition showed that MT treatment has significantly increased moisture and decreased ether extract than other treatments. The effects of phytochemicals showed a slight improvement of protein and ether extract content compared to the control diet. Consequently, it can be concluded that the use of phytochemicals in fish diets as growth promoters is more effective than sex-reversal agents. It is recommended to use TTE in Nile tilapia fry diets.
\end{abstract}

Key words: Oreochromis niloticus; Phytochemicals; Sex-reversal; Growth performance

\section{INTRODUCTION}

The demand for animal protein has gone far beyond supply as a result of the rapid growth of human population in the many countries of the world, especially in the developing countries. An urgent need is therefore necessary to increase the production of protein sources. Nowadays, aquaculture is one of the fastest growing food production sectors and an increasingly important option in animal protein sources in the world. Farmed tilapias have been an important global commodity since the 1990s. The global production of farmed tilapias reached approximately 3.5 million tons in 2012, second only to farmed carps (FAO, 2012). Their ability to grow on a wide range of diets, fast growth, high conversion ratio and reproduce readily in captivity makes them attractive for culture (El-Sayed, 2006).

Despite having many good characteristics, one of the major obstacles in commercial tilapia production is its precocious maturity and the following uncontrolled reproduction, resulting in an increasing competition for feed followed by stunted growth and low commercial value (Wassermann and Afonso, 2003). 
Moreover, the sex of fish can be significant in aquaculture because of differences between males and females in growth rate, size, behavior patterns, and breeding time (Turan and Cek, 2007). In populations of tilapia, males grow faster and are more uniform in size than females (Tariq-Ezaz et al., 2004). All male tilapia achieved using methyl testosterone treatment, it was the most popular and successful practice all over the world (Abdelhamid et al., 2009).

Because of consumer concerns and strict regulations in many countries, the use of synthetic chemicals, hormones and antibiotics is becoming unviable and natural compounds are more acceptable to the public (Chakraborty et al., 2013). Furthermore, the synthetic hormones have been reported to have the potential to accumulate in the sediment water and aquatic biota (Contreras-Sanchez et al., 2001; Çek et al., 2004). Farthermost, methyl testosterone (MT) is considered to be carcinogenic (Velazquez and Alter, 2004).

Phytochemicals contained in herbs may enhance the innate immune system, possess antimicrobial capabilities, and are redox active molecules with antioxidant characteristics that may help to improve the general physiological condition of fish (Chakraborty et al., 2013).

Moreover, many of the phytochemicals reported to stimulate testosterone secretion such as ginseng extract (Tsai et al., 2003). Also, Tribulus terrestris extract (TTE) increased testosterone level and improve sexual status (Gauthaman and Adaikan, 2008). Furthermore, the effect of DPP on testosterone augmentation were emphasized via numerous authors and different species model e.g. Marbeen et al. (2005) on human and Abedi et al. (2012) on rat.

Therefore these findings lead to the expected effect of phytochemicals as sex-reversal agent on fish, where Nakari and Erkomaa (2003) reported that phytochemicals modulate endocrine function and changed the sex ratio of the exposed Zebra fish fry. Considering these aspects, the present study was focused to evaluate the efficacy of three phytochemicals (ginseng extract, Tribulus terrestris extract and date palm pollen) as natural alternative sex-reversal agents and growth promoters of Nile tilapia (O. niloticus) fry instead of methyl testosterone.

\section{MATERIALS AND METHODS}

The present work was conducted to investigate the effect of ginseng extract, Tribulus terrestris extract and date palm pollen against 17 a-methyl testosterone (MT) on sex reversal, survival rate, growth performance, feed utilization and whole body chemical composition of Nile tilapia (O. niloticus) fry. This experiment was carried out at the Laboratory of Fish Nutrition, Faculty of Agriculture (Saba-Basha), Alexandria University, Egypt.

\section{Experimental fish and design}

Nile tilapia fry one day old (weighing $0.02 \mathrm{~g} /$ fry and measuring $1.13 \mathrm{~cm}$ total length/fry) were obtained from a private commercial hatchery sited in Motobas, Kafr-El Sheikh Governorate, Egypt. The fry kept in glass aquaria for one day after transportation without feeding. A total of 800 tilapia fry were randomly distributed on 16 glass aquaria $(100 \times 30 \times 40 \mathrm{~cm})$ each $100 \mathrm{~L}$ of water, which were continuously aerated with air stone. The aquarium was static bath with changing water 
manually, and the used siphon tube was closed by hapa net to prevent fry escaping. The photoperiod was maintained on a (12:12) light:dark schedule and temperature $\left(25 \pm 2^{\circ} \mathrm{C}\right)$.

The starting fish density was 50 larvae per aquarium with two replicates per treatment. The following eight treatments were performed, control fed basal diet without supplementation, or basal diet supplemented with MT $(60 \mathrm{mg} / \mathrm{kg}), \mathrm{GE}(0.2$ or $0.4 \mathrm{~g} / \mathrm{kg}$ ), TTE (0.6 or $1.2 \mathrm{~g} / \mathrm{kg}$ ) and DPP (3 or $6 \mathrm{~g} / \mathrm{kg}$ ) in diet. The treatments received experimental diets for 84 days except MT treatment lasted for 28 days and completed with the basal diet, until the end of experiment.

\section{Experimental diets and sex-reversal agents}

The sex-reversal agents were MT (ARGENT laboratories Inc. Philippines), GE (Pharco Pharmaceuticals Co., Alexandria, Egypt), TTE (Nerhadou International Co. for pharmaceuticals and nutraceuticals, Egypt) and DPP: Fresh pollen of date palm was collected in March 2013 from Edku city, Egypt. The pollens were separated from the kernels with a fine gauze sieve and dried at $50^{\circ} \mathrm{C}$ for $24 \mathrm{hrs}$.

The experimental diets were formulated in powder form and its chemical composition is shown in Table (1). The sex-reversal (MT, GE, TTE and DPP) treatments were prepared according to the alcohol evaporation method (Guerrero, 1975; Navarro-Martín et al., 2009). The control diet was treated with ethanol only and then the diet was left to dry at room temperature in front of an electric fan for 12 hours. Fish were fed three times a day in a decreasing rate from 20 to $10 \%$ of live body weight for 4 weeks, and then the fish were fed at $8 \%$ to the end of the experiment, the feed ratio adjusted every week.

\section{Table (1): Ingredient and chemical composition (\%) of the experimental diets.}

\begin{tabular}{|c|c|}
\hline Ingredients & Basal diet \\
\hline Fish meal (herring; 72\%) & 56.4 \\
\hline Wheat flour & 40 \\
\hline Corn oil & 2 \\
\hline Vitamins and Minerals primex ${ }^{1}$ & 0.5 \\
\hline Vitamin C & 0.5 \\
\hline Garlic Extract & 0.1 \\
\hline Oxytetracyclin & 0.5 \\
\hline \multicolumn{2}{|c|}{ Chemical composition (\% on dry matter basis) } \\
\hline Dry matter (DM) & 93.70 \\
\hline Crud protein $(\mathrm{CP})$ & 44.16 \\
\hline Ether extract & 7.23 \\
\hline Nitrogen free extract (NFE) & 40.14 \\
\hline Crude fiber & 4.17 \\
\hline Ash & 6.03 \\
\hline Gross energy (GE; kcal/100g DM) ${ }^{2}$ & 486.67 \\
\hline $\mathrm{P} / \mathrm{E}$ ratio $(\mathrm{mg} \text { protein } / \mathrm{kcal})^{3}$ & 90.74 \\
\hline
\end{tabular}


${ }^{2}$ Gross energy, calculated on the basis of $5.64,9.44$ and $4.11 \mathrm{kcal} \mathrm{GE} / \mathrm{g}$ protein, ether extract and NFE respectively (NRC, 1993).

${ }^{3}$ Protein/ energy ratio $(\mathrm{mg}$ protein/kcal gross energy $)=\mathrm{CP} / \mathrm{GE} \times 1000$

\section{Measured parameters Sex ratio analysis}

At the end of the experiment, gonads were then sampled and examined directly by studying wet-squash preparations according to Guerrero and Shelton (1974). Briefly, the gonads were removed using fine forceps, placed on a slide, covered with few drops of aceto-carmine stain and squashed with a cover slip. The slide was then examined under a compound microscope using magnifications of $10 * 40 \mathrm{X}$.

\section{Growth performance and feed utilization parameters}

At trial termination, all fish were weighed and measured (Total length), and their condition factor (CF) calculated according to the following equation: $\mathrm{CF}=$ (weight/length $\left.{ }^{3}\right)^{*} 100$; Specific growth rate (SGR; \%/day) was calculated using the equation: SGR $=(($ natural $\log$ of final weight $\{g\}$ - natural log of initial weight $\left.\{g\})^{\star} 100\right)$ / t (days), also survivalrate was noted throughout the study. Feed conversion ratio (FCR) was calculated according to the following equation: $\mathrm{FCR}=$ (feed intake/ weight gained); protein efficiency ratio (PER) calculated as weight gain/ protein intake.

\section{body chemical composition}

Proximate chemical analyses (\%) of the diet and body after the experiment were performed according to the official methods of analysis of the AOAC (1995). Nitrogen free extract (NFE) in the experimental diets were calculated using the following equation: NFE $=100$ - $($ Crude Protein + Ether Extract + Crude fiber + Ash).

\section{Statistical analysis}

Data were statistically analyzed with one-way ANOVA and Duncan's multiple range tests and expressed as mean values \pm SE. In addition, effects with a probability of $P<0.05$ were considered significant. Statistical analyses were performed using SPSS for Windows (Standard Version 17 SPSS Inc. Chicago, Illinois).

\section{RESULTS}

The highest significant male percent $(92.30 \%)$ was observed in MT treatment compared to other treatments; and the control group recorded the lowest male ratio $(48.36 \%)$. The male percent skewed via dietary TTE $(0.6 \mathrm{~g} / \mathrm{kg}$ diet $)$, TTE (1.2 g/kg diet) and DPP (6 g/kg diet) to be 57.76, 64.48 and $56.67 \%$, respectively. The best sex reversal ratio in TTE in high dose $(1.2 \mathrm{~g} / \mathrm{kg}$ diet) treatment, indicating that TTE affect male percent in dose-dependently.

The dietary Ginseng extract treatments $(0.2$ or $0.4 \mathrm{~g} / \mathrm{kg}$ diet) and Date palm pollen ( $3 \mathrm{~g} / \mathrm{kg}$ diet) didn't affect statistically the male percent compared to control, and were nearly expected ratio of 1:1 (male: female). The inter sex has shown only 
with MT and TTE (1.2 g/kg diet) treatments, concomitantly to rise of sex reversal process (Fig. 1).

The overall survival rate (\%) ranged from $94 \%$ to $96.5 \%$ after the first 28 days of treatment, meanwhile after 84 days the survival rate varying from $89 \%$ to $92 \%$, without any significant drastic effect of all studied treatments (Fig. 2). The noticed mortality couldn't be attributed to any obvious cases and considered acceptable during this period of $(O$. niloticus) fry live span.

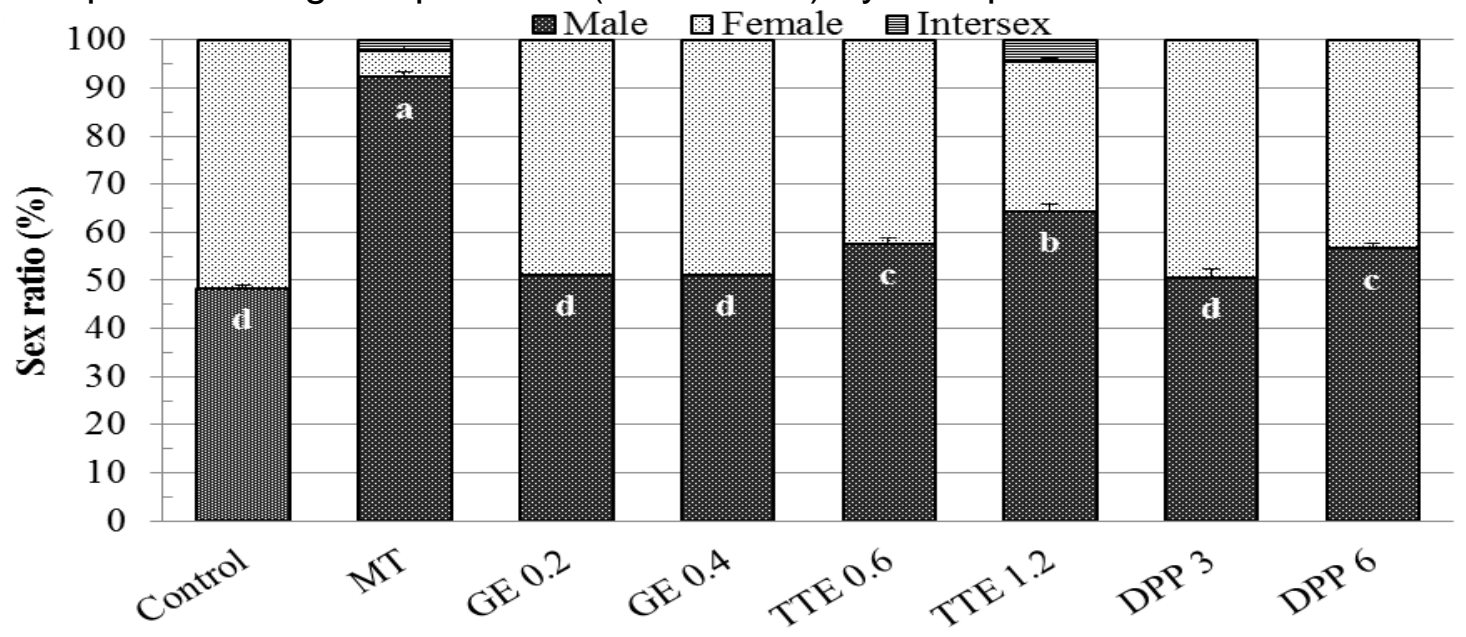

Figure (1): Effect of different phytochemicals (g/kg diet) compared with $17 \alpha-$ methyl testosterone (MT) on sex ratio of Nile tilapia (O. niloticus) fry. GE, ginseng extract; TTE, Tribulus terrestris extract; DPP, date palm pollen.

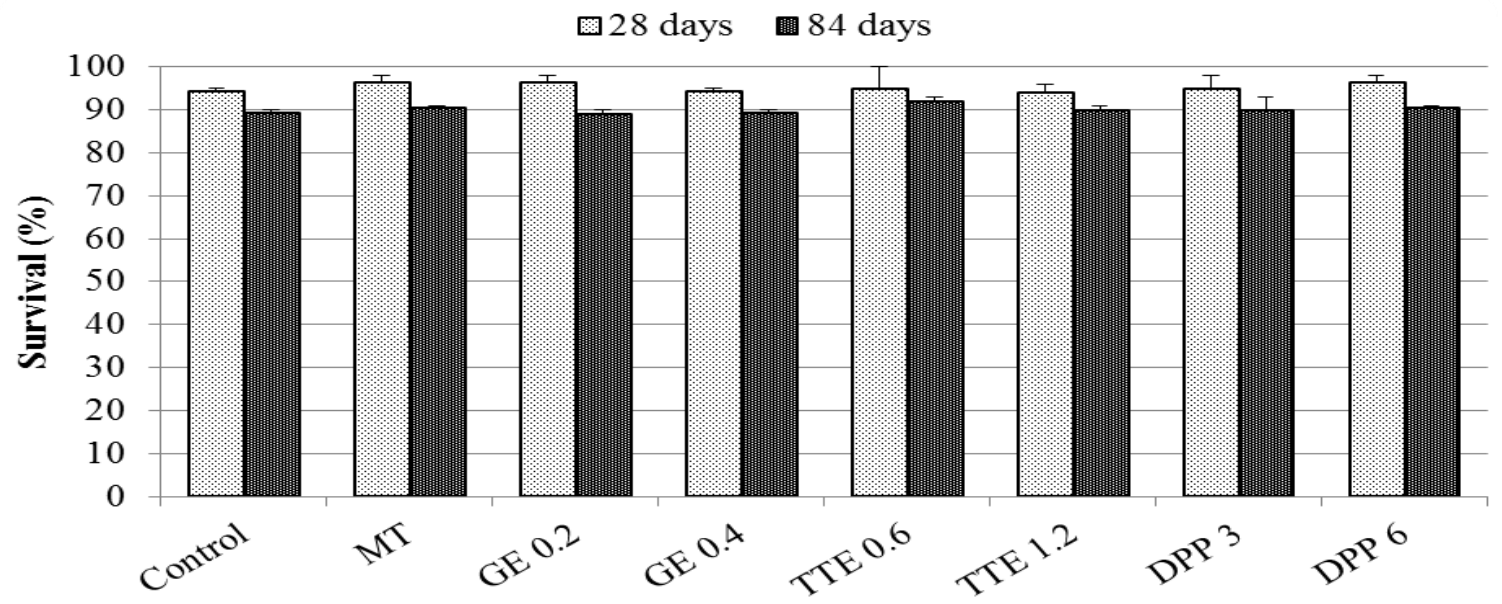

Figure (2): Effect of different phytochemicals ( $\mathrm{g} / \mathrm{kg}$ diet) compared with $17 \alpha-$ methyl testosterone (MT) on survival rate (\%) of Nile tilapia $(O$. niloticus) fry. GE, ginseng extract; TTE, Tribulus terrestris extract; DPP, date palm pollen. 
The effect of different sex-reversal agents on growth performance of 0 . niloticus after 28 and 84 days of treatments showed in Table 2 . At 28 and 84 days of treatment the final body weight ( $\mathrm{g} / \mathrm{fish})$ and SGR (\%/day) of all studied treatments increased compared with control diet and the highest FBW and SGR after 28 days observed with TTE $1.2 \mathrm{~g} / \mathrm{kg}$ diet followed by GE $0.4 \mathrm{~g} / \mathrm{kg}$ diet meanwhile after 84 days the MT treatment recorded the best FBW and SGR followed by TTE $1.2 \mathrm{~g} / \mathrm{kg}$ diet and GE $0.4 \mathrm{~g} / \mathrm{kg}$ diet with insignificant differences among them. The total length didn't differ significantly after 28 days of treatment, meanwhile after 84 days the length of MT treated fish significantly surpassed the control total length and the other treatments insignificantly. Moreover, the condition factor didn't differ significantly after 28 or 84 days of treatment.

Table (2): Effect of different phytochemicals ( $\mathrm{g} / \mathrm{kg} \mathrm{diet)} \mathrm{compared} \mathrm{with} 17 \alpha-$ methyl testosterone on final body weight (g/fish), SGR (\%/day), length (cm/fish) and condition factor of Nile tilapia (O. niloticus) fry.

\begin{tabular}{|c|c|c|c|c|c|c|c|c|}
\hline \multirow{2}{*}{ Items } & \multicolumn{2}{|c|}{$\begin{array}{c}\text { Final body weight } \\
\text { (g/fish) }\end{array}$} & \multicolumn{2}{|c|}{ SGR (\%/day) } & \multicolumn{2}{|c|}{ Length (cm) } & \multicolumn{2}{|c|}{ Condition factor } \\
\hline & 28 days & 84 days & 28 days & 84 days & 28 days & 84 days & 28 days & 84 days \\
\hline Control & $0.70 \pm 0.01^{d}$ & $5.66 \pm 0.12^{c}$ & $13.20 \pm 0.05^{d}$ & $6.03 \pm 0.01^{c}$ & $3.54 \pm 0.05$ & $6.78 \pm 0.21^{b}$ & $1.5 \pm 0.07$ & $1.82 \pm 0.13$ \\
\hline MT & $0.83 \pm 0.01^{\mathrm{bcd}}$ & $7.23 \pm 0.29^{\mathrm{a}}$ & $13.81 \pm 0.06^{\mathrm{bc}}$ & $6.29 \pm 0.06^{a}$ & $3.70 \pm 0.04$ & $7.19 \pm 0.00^{\mathrm{a}}$ & $1.63 \pm 0.05$ & $1.95 \pm 0.08$ \\
\hline GE 0.2 & $0.89 \pm 0.02^{\mathrm{abc}}$ & $6.01 \pm 0.13^{b c}$ & $14.08 \pm 0.16^{\mathrm{abc}}$ & $6.10 \pm 0.05^{\mathrm{abc}}$ & $3.58 \pm 0.06$ & $6.99 \pm 0.07^{\mathrm{ab}}$ & $1.94 \pm 0.06$ & $1.76 \pm 0.02$ \\
\hline GE 0.4 & $0.97 \pm 0.08^{\mathrm{ab}}$ & $6.31 \pm 0.47^{\mathrm{abc}}$ & $14.36 \pm 0.36^{\mathrm{ab}}$ & $6.15 \pm 0.05^{\mathrm{abc}}$ & $3.69 \pm 0.07$ & $6.97 \pm 0.11^{\mathrm{ab}}$ & $1.93 \pm 0.26$ & $1.86 \pm 0.05$ \\
\hline TTE 0.6 & $0.80 \pm 0.02^{\mathrm{cd}}$ & $6.22 \pm 0.39^{\mathrm{abc}}$ & $13.70 \pm 0.17^{\mathrm{cd}}$ & $6.13 \pm 0.04^{\mathrm{abc}}$ & $3.58 \pm 0.02$ & $7.06 \pm 0.16^{\mathrm{ab}}$ & $1.74 \pm 0.01$ & $1.77 \pm 0.01$ \\
\hline TTE 1.2 & $1.01 \pm 0.07^{\mathrm{a}}$ & $6.92 \pm 0.31^{\mathrm{ab}}$ & $14.53 \pm 0.17^{\mathrm{a}}$ & $6.24 \pm 0.02^{\mathrm{ab}}$ & $3.71 \pm 0.05$ & $7.18 \pm 0.05^{\mathrm{ab}}$ & $1.97 \pm 0.06$ & $1.87 \pm 0.04$ \\
\hline DPP 3 & $0.90 \pm 0.01^{\mathrm{abc}}$ & $5.87 \pm 0.35^{\mathrm{bc}}$ & $14.12 \pm 0.04^{\mathrm{abc}}$ & $6.07 \pm 0.09^{b c}$ & $3.64 \pm 0.04$ & $6.87 \pm 0.08^{\mathrm{ab}}$ & $1.88 \pm 0.09$ & $1.82 \pm 0.17$ \\
\hline DPP 6 & $0.84 \pm 0.04^{\mathrm{bc}}$ & $5.91 \pm 0.34^{\mathrm{bc}}$ & $13.88 \pm 0.09^{b c}$ & $6.08 \pm 0.08^{b c}$ & $3.63 \pm 0.04$ & $6.80 \pm 0.11^{\mathrm{ab}}$ & $1.76 \pm 0.15$ & $1.88 \pm 0.20$ \\
\hline
\end{tabular}

All diets were acceptable for all treatments, which appeared in insignificant feed intake after 28 and 84 days of feeding treatment, the same pattern reflexed in protein intake. The feed conversion ratio was improved in all supplementation treatments than the control group. The best FCR was observed with TTE $1.2 \mathrm{~g} / \mathrm{kg}$ diet followed by GE $0.4 \mathrm{~g} / \mathrm{kg}$ diet after 28 days. Meanwhile, the MT treatment showed the best FCR followed by TTE $1.2 \mathrm{~g} / \mathrm{kg}$ diet after 84 days of treatment. The same manner was observed with PER (Table 3).

Moisture content (\%) of whole fish body ranged from 72.6 to $75.7 \%$ without significant differences among all treatments except the significant increase of moisture content of MT treated fish than other treatment. The highest protein content was recorded with TTE $0.6 \mathrm{~g} / \mathrm{kg}$ diet followed by GE $0.4 \mathrm{~g} / \mathrm{kg}$ diet with significant increase compared to control. The protein content of other treatment didn't significantly differ from the control. The ether extract significantly dropped with MT treatment by $28.67 \%$ compared to control. Meanwhile, other treatment didn't differ significantly than control, except TTE $1.2 \mathrm{~g} / \mathrm{kg}$ diet and DPP $6 \mathrm{~g} / \mathrm{kg}$ diet. The ash content of fish body showed significant differences among treatments with the highest values with DDP $6 \mathrm{~g} / \mathrm{kg}$ diet and control, meanwhile, the lowest ash mean recorded with GE $0.2 \mathrm{~g} / \mathrm{kg}$ diet (Table 4). 
Table (3): Effect of different phytochemicals ( $\mathrm{g} / \mathrm{kg} \mathrm{diet)} \mathrm{compared} \mathrm{with} 17 \alpha-$ methyl testosterone on feed intake, protein intake, feed conversion ratio (FCR) and protein efficiency ratio (PER) of Nile tilapia ( $O$. niloticus) fry.

\begin{tabular}{lcccccccc}
\hline \hline \multirow{2}{*}{ Items } & \multicolumn{2}{c}{ Feed intake $(\mathbf{g})$} & \multicolumn{2}{c}{ FCR $(\mathbf{g})$} & \multicolumn{2}{c}{ Protein intake $(\mathbf{g})$} & \multicolumn{2}{c}{ PER $(\mathbf{g})$} \\
\cline { 2 - 8 } & $\mathbf{2 8}$ days & $\mathbf{8 4}$ days & $\mathbf{2 8 ~ d a y s}$ & $\mathbf{8 4}$ days & 28 days & $\mathbf{8 4 ~ d a y s}$ & 28 days & $\mathbf{8 4 ~ d a y s}$ \\
\hline Control & $0.94 \pm 0.03$ & $8.10 \pm 0.28$ & $1.38 \pm 0.03^{\mathrm{a}}$ & $1.44 \pm 0.02^{\mathrm{a}}$ & $0.41 \pm 0.01$ & $3.58 \pm 0.13$ & $1.64 \pm 0.04^{\mathrm{d}}$ & $1.58 \pm .02^{\mathrm{c}}$ \\
MT & $0.95 \pm 0.05$ & $8.22 \pm 0.01$ & $1.18 \pm 0.05^{\mathrm{bcd}}$ & $1.14 \pm 0.05^{\mathrm{c}}$ & $0.42 \pm 0.02$ & $3.63 \pm 0.00$ & $1.93 \pm 0.09^{\mathrm{abcd}}$ & $1.99 \pm 0.08^{\mathrm{a}}$ \\
GE 0.2 & $1.01 \pm 0.01$ & $8.11 \pm 0.09$ & $1.16 \pm 0.04^{\mathrm{bcd}}$ & $1.35 \pm 0.01^{\mathrm{ab}}$ & $0.45 \pm 0.00$ & $3.58 \pm 0.04$ & $1.96 \pm 0.06^{\mathrm{abc}}$ & $1.67 \pm 0.02^{\mathrm{bc}}$ \\
GE 0.4 & $1.03 \pm 0.03$ & $8.19 \pm 0.05$ & $1.09 \pm 0.05^{\mathrm{cd}}$ & $1.31 \pm 0.10^{\mathrm{abc}}$ & $0.46 \pm 0.01$ & $3.62 \pm 0.02$ & $2.08 \pm 0.10^{\mathrm{ab}}$ & $1.74 \pm 0.14^{\mathrm{abc}}$ \\
TTE 0.6 & $1.00 \pm 0.00$ & $8.03 \pm 0.12$ & $1.28 \pm 0.03^{\mathrm{ab}}$ & $1.30 \pm 0.06^{\mathrm{abc}}$ & $0.44 \pm 0.00$ & $3.54 \pm 0.05$ & $1.77 \pm 0.05^{\mathrm{cd}}$ & $1.75 \pm 0.08^{\mathrm{abc}}$ \\
TTE 1.2 & $1.04 \pm 0.00$ & $8.06 \pm 0.16$ & $1.05 \pm 0.07^{\mathrm{d}}$ & $1.17 \pm 0.03^{\mathrm{bc}}$ & $0.46 \pm 0.00$ & $3.56 \pm 0.07$ & $2.16 \pm 0.15^{\mathrm{a}}$ & $1.94 \pm 0.05^{\mathrm{ab}}$ \\
DPP 3 & $1.05 \pm 0.03$ & $7.95 \pm 0.75$ & $1.19 \pm 0.02^{\mathrm{bcd}}$ & $1.35 \pm 0.05^{\mathrm{ab}}$ & $0.47 \pm 0.01$ & $3.51 \pm 0.33$ & $1.90 \pm 0.04^{\mathrm{abcd}}$ & $1.67 \pm 0.06^{\mathrm{bc}}$ \\
DPP 6 & $1.01 \pm 0.01$ & $7.99 \pm 0.00$ & $1.23 \pm 0.05^{\mathrm{abc}}$ & $1.36 \pm 0.08^{\mathrm{ab}}$ & $0.45 \pm 0.00$ & $3.53 \pm 0.00$ & $1.84 \pm 0.07^{\mathrm{bcd}}$ & $1.67 \pm 0.10^{\mathrm{bc}}$
\end{tabular}

* Values superscripted by different alphabets within the same column are significantly different $(P<0.05)$. GE, ginseng extract; TTE, Tribulus terrestris extract; DPP, date palm pollen.

Table (4): Effect of different phytochemicals ( $\mathrm{g} / \mathrm{kg} \mathrm{diet)} \mathrm{compared} \mathrm{with} 17 \alpha-$ methyl testosterone on whole body composition (\% of wet weight) of Nile tilapia (O. niloticus) fry.

\begin{tabular}{l|llll}
\hline \multirow{2}{*}{ Items } & \multicolumn{4}{|c}{$\%$ on wet weight basis } \\
\cline { 2 - 5 } & Moisture (\%) & Protein (\%) & Ether extract (\%) & Ash (\%) \\
\hline Control & $73.30 \pm 0.20^{\mathrm{b}}$ & $14.59 \pm 0.13^{\mathrm{c}}$ & $8.37 \pm 0.03^{\mathrm{c}}$ & $3.70 \pm 0.13^{\mathrm{ab}}$ \\
MT & $75.70 \pm 0.60^{\mathrm{a}}$ & $14.86 \pm 0.11^{\mathrm{bc}}$ & $5.97 \pm 0.05^{\mathrm{d}}$ & $3.45 \pm 0.13^{\mathrm{abc}}$ \\
GE 0.2 & $73.15 \pm 0.35^{\mathrm{b}}$ & $14.96 \pm 0.13^{\mathrm{bc}}$ & $8.64 \pm 0.06^{\mathrm{bc}}$ & $3.23 \pm 0.11^{\mathrm{c}}$ \\
GE 0.4 & $73.10 \pm 0.10^{\mathrm{b}}$ & $15.06 \pm 0.15^{\mathrm{b}}$ & $8.56 \pm 0.14^{\mathrm{bc}}$ & $3.28 \pm 0.06^{\mathrm{c}}$ \\
TTE 0.6 & $73.00 \pm 1.00^{\mathrm{b}}$ & $15.52 \pm 0.19^{\mathrm{a}}$ & $8.28 \pm 0.25^{\mathrm{c}}$ & $3.20 \pm 0.12^{\mathrm{c}}$ \\
TTE 1.2 & $72.80 \pm 0.10^{\mathrm{b}}$ & $15.00 \pm 0.20^{\mathrm{bc}}$ & $8.90 \pm 0.16^{\mathrm{ab}}$ & $3.30 \pm 0.14^{\mathrm{c}}$ \\
DPP 3 & $73.35 \pm 0.25^{\mathrm{b}}$ & $14.67 \pm 0.13^{\mathrm{bc}}$ & $8.65 \pm 0.05^{\mathrm{bc}}$ & $3.35 \pm 0.15^{\mathrm{bc}}$ \\
DPP 6 & $72.60 \pm 0.50^{\mathrm{b}}$ & $14.61 \pm 0.06^{\mathrm{bc}}$ & $9.05 \pm 0.13^{\mathrm{a}}$ & $3.74 \pm 0.10^{\mathrm{a}}$ \\
\hline
\end{tabular}

* Values superscripted by different alphabets within the same column are significantly different $(P<0.05)$. GE, ginseng extract; TTE, Tribulus terrestris extract; DPP, date palm pollen.

\section{DISCUSSION:}

The target of the present study was to find an alternative sex-reversal method to induce all male tilapia fry and improve growth performance, for the method currently used to be more effective, easy and environmental friendly. Toward this goal, some phytochemicals were incorporated in diet of O. niloticus fry in a comparison with MT treatment. The use of phytochemicals as sex-reversal agents in fish is a recent research area. Mirza and Shelton (1988) reported that the manipulation of biological synthesis of steroids have a similar effect to the administration of exogenous steroid hormones. During the specific critical periods of early gonad development, changes in sex hormone levels can affect the final sex independently of the genetic sex (Andersen et al., 2003). Consequently, 
embryonic differentiation of the fetus into a male and its subsequent growth along this line is essentially due to the presence of physiological amounts of androgens (especially testosterone and its metabolite dihydrotestosterone) in the body (Baskin et al., 1997).

From the current findings, the MT treatment was the most effective treatment on sex-reversal of $O$. niloticus. However, synthetic hormones and hormone metabolites persistence and their fate in fish, water and sediment will provide information on the potential risks of using hormonal sex control technology (Contreras-Sanchez et al., 2001). Fish offered to the consumer will not be treated with synthetic hormones and producers may have an alternative method for producing of monosex populations based on natural products (Yılmaz et al., 2009).

Among studied phytochemicals, TTE treatments were the most effective treatment on sex differentiation of $O$. niloticus fry and increasing male ratio in the offspring with the maximum ratio57.76 and $64.48 \%$, respectively. Meanwhile the other phytochemical treatments didn't have obvious effect on sex ratio skewness. Turan and Cek (2007) reported increase in male sex ratio of Clarias gariepinus, as a dose dependent manner with TTE treatment and the highest male ratio $(80.42 \%)$ recorded with $9 \mathrm{~g}$ TTE as immersion in 30L water. Moreover, the male percent reached to $87.23 \%$ via immersion of newly hatched Convict Cichlid, Cichlasoma nigrofasciatum, fry once a week for two months on TTE extract (Çek et al., 2007a). The increase in the sex ratio than the present study may be attributed to the alteration of the TTE application methods, doses and species. In accordance, Omitoyin et al. (2013) found that percentage of males in treated fish increased as concentration of TTE increased up to reach $85.7 \%$ with $2.5 \mathrm{~g} / \mathrm{kg}$ diet. This findings mount our results by $20 \%$ and this could be the used of double dose of TTE than used in our study. The effect of TTE to increase male percent may be due to the increase of androgens production, where TTE contains a number of different substances including steroidal saponins. Protodioscin, the most dominant saponin in TTE, is thought to be the main substance responsible for increasing testosterone production (Ganzera et al., 2001), dehydroepiandrosterone (Adimoelja and Adaikan, 1997), dihydrotestosterone, and dehydroepiandrosterone sulfate (Gauthaman et al., 2000).

Although, the other studied phytochemicals GE and DPP showed improvement effects on testosterone secretion (Tsai et al., 2003; Abedi et al., 2012), its effect on sex reversal is weak. This can be interpreted to its mechanism to promote testosterone secretion is different than TTE, where each GE and DPP act on the pituitary gland level and promote luteinizing hormone secretion, hence increase testosterone production (El-Desoky, 1995; Salvati et al., 1996). Meanwhile, TTE reported to increase luteinizing hormone secretion (pituitary level) and act as testosterone precursor (testes level) (Bucci, 2000; Gauthaman et al., 2002).

Intersex fingerlings were recorded with MT and TTE $(1.2 \mathrm{~g} / \mathrm{kg}$ diet $)$ treatments. As sexing of fish was performed 84days after the treatment period, it might have been speculated that a $100 \%$ sex reversal was induced by MT treatment and the fish reversed back to their original sex when the effects of MT diminished (Piferrer and Lim, 1997). Meanwhile, in the case of TTE, the treatment 
continue for last of the experiment, so the intersex occurrence didn't due to the back reverse of sex, it may be caused by incomplete differentiation process.

The survival rate after 28 and 84 days of experiment wasn't reduced by any studied treatments compared to control. These findings revealed that the used treatments didn't have potent toxic effect on studied fish. This result in accordance with the studied of Adimoelja (2000) and Adaikan et al. (2000), they have presented evidence that TTE is not toxic to humans and rabbits, respectively. Also, from the previous literature, ginseng (Goda, 2008) and date palm pollen (Iftikhar et al., 2011) didn't report any toxicity cases.

In agreement with MT effect on improving growth performance, considerable informationis available on the growth promoting efficiency of anabolic steroid hormones in fishes (Felix, 1989; Tveiten et al.,1998; Asad et al., 2010; Norbeck and Sheridan, 2011). The acceleration of growth due to MT treatment may due to the increase of growth hormone mRNA production in pituitary gland above basal levels when the fish treated with MT (Huggard et al., 1996).

The use of phytochemicals treatments increased growth performance (FBW, SGR and length) rather than control. Meanwhile, the effects on condition factor didn't clearly appear. Furthermore, the phytochemicals inclusion to fish diets increase feed and nutrients utilization compared to control in the case of FCR and PER, without significant effects on feed intake and consequently protein intake. In accordance, ginseng helps regulate body functions, specifically improve adaptability and is believed to help build muscle and endurance (Francis et al., 2002). In accordance, Goda (2008) found a significant increase in growth performance and feed utilization of Nile tilapia (O. niloticus) fed diets supplemented with ginseng extract 50, 100, 150, 200, and $250 \mathrm{mg} / \mathrm{kg}$ diet. Also, Yan et al. (2011) found that the addition of $0.1 \%$ wild-ginseng adventitious root to the diet increased growth performance of broilers chicken.

Parallel results to our findings reported by Gauthaman et al. (2002) in rats who found an increase in body weight due to TTE treatment. New-born guppies (Poecilia reticulata) treated with TTE extract exhibit successful growth acceleration comparing to control group especially with the concentration 0.1 and $0.15 \mathrm{~g} / \mathrm{L}$ which reached to 4.5 time more than control for the two concentration (Cek et al., 2007b). Moreover, Cek et al. (2007a) investigate the effect of higher doses of TTE extract $(0.0,0.10,0.20$ and $0.30 \mathrm{~g} / \mathrm{l})$ on growth and survival of convicted cichlid, the $0.3 \mathrm{~g} / \mathrm{l}$ TTE extract improved growth rate 1.6 times more than control, the survival rate was uniformly high in control and treated group ranging from 88.57 to $90 \%$.

In the case of DPP, the current findings in accordance with Iftikhar et al. (2011).The authors found that rat treated with $120 \mathrm{mg} / \mathrm{kg}$ daily had normal food intake and didn't have any negative effect on the survival of experimental animals. Attia et al. (2011) reported that rabbit offspring received a water solution containing 0, 100, 200 and $300 \mathrm{mg}$ bee pollen/kg body weight, twice per week for 12 week, showed improvement in growth performance in bee pollen groups than control. The Bee pollen at $200 \mathrm{mg} / \mathrm{kg} \mathrm{BW}$ reveal increase in weight gain and survival rate and reduced feed intake and feed conversion ratio of offspring. Furthermore, Abbass et al. (2012) investigate the supplementation of Nile tilapia (O. niloticus) diet with $2.5 \%$ of honeybee pollen for 21 days. The results showed that dietary honey bee 
pollen significantly improved length, specific growth rate, average daily gain and feed efficiency ratio. On the other hand, Hassan et al. (2012) study the effect of $240 \mathrm{mg} \mathrm{DPP} / \mathrm{kg}$ body weight of adult male albino rats daily for 30 days, the weight of treated adult male rat didn't differ compared to the control.

From a chemical composition point of view, the MT treatment increased moisture and decreased ether extract content than control and other treatments, meanwhile other treatments didn't affect the moisture level. The application of phytochemicals slightly increased protein content than control. Moreover, ether extract content decreased with the MT treatment. The effect of phytochemicals didn't clearly appear on the whole body composition in our study. The same trend was observed by Goda (2008), where whole body proximate analysis didn't present any statistical differences for dietary Ginsana ${ }^{\circledR}$ levels. In contrast, Yan et al. (2011) found that ginseng induced a linear decrease in abdominal fat in broilers chicken.

\section{CONCLUSION:}

The findings of this study indicated that, the use of phytochemicals in fish diets is more growth promoter than sex-reversal agents in Nile tilapia (O. niloticus). Meanwhile, the probability of using TTE as an alternative agent for production of monosex Nile tilapia population is likely to occur. However, further investigation will be required to determine the optimum treatment regime for induction of $100 \%$ sex reversal with this phytochemical.

\section{REFERENCES:}

Abbass, A.A., El-Asely, A.M. and Kandiel, M.M.M. (2012). Effects of dietary propolis and pollen on growth performance, fecundity and some hematological parameters of Oreochromis niloticus. Turkish J. Fish Aquat. Sci., 12: 851-859.

Abdelhamid, A.M., Mehrim, A.I., Salem, M.F.I. and Yosuf, H.A.E. (2009). Allmale monosex Nile tilapia (Oreochromis niloticus), pros and cons. Egypt J. Basic Appl. Physiol., 8:41-57.

Abedi, A., Parviz, M., Karimian, S.M. and Sadeghipour, H.R. (2012). The Effect of Aqueous Extract of Phoenix DactyliferaPollen Grain on Sexual Behavior of Male Rats. J. Physiol. Pharmacol. Adv., 2: 235-242.

Adaikan, P.G., Gauthaman, K., Ng, R.N.V. and Prasad, S.C. (2000). Proerectile pharmacological effects of Tribulus terrestris on the rabbit corpus cavernosum. Ann. Acad. Med. Singapore, 29:22-26.

Adimoelja, A. and Adaikan, P.G. (1997). Protodioscin from herbal plant Tribulus terrestris L. improves male sexual functions possibly via DHEA. Int. J. Impot. Res., 9:64.

Adimoelja, A. (2000).Photochemical and the breakthrough of traditional herbs in the management of sexual dysfunctions. Int. J. Androl., 23:82-84.

Andersen,L., Holbech, H., Gessbo. A., Norrgen, L. and Petersen, G.I. (2003). Effect of exposure to 17a-ethinylestradiol during early development on sexual differentiation and induction of vitellogenin in zebra fish (Daniorerio). Comp. Biochem. Physiol. C., 134:365-374. 
AOAC. (1995). Official methods of analysis. $16^{\text {th }}$ edition, Arlington, VA, USA.

Asad, F., Ahmed, I., Saleem, M. and Iqbal, T. (2010). Hormonal masculinization and growth performance in Nile tilapia (Oreochromis niloticus) by androgen administration at different dietary protein levels. Int. J. Agr. Biol., 12: 939943.

Attia, Y.A., Al-Hanoun, A. and Bovera, F. (2011). Effect of different levels of bee pollen on performance and blood profile of New Zealand White bucks and growth performance of their offspring during summer and winter months. J. Anim. Physiol. Anim. Nutr., 95: 17-26.

Baskin, L.S., Sutherland, R.S., Di Sandro, M.J., Hayward, S.W., Lipschutz, J. and Cunha, G.R. (1997). The effect of testosterone on androgen receptors and human penile growth. J. Urol., 158: 1113-1118.

Bucci, L.R. (2000). Selected herbals and human exercise performance. Am. J. Clin. Nutr., 72:624-636.

Çek, Ş., Yıldırım, Y., Şereflişan, H. and Akyurt, I. (2004). Sex Control in Aquaculture In: Harmancıoğlu O, Fıstıkoğlu Y, Dalgılıç D, Gül A (Eds) Water Resources Management; Risks and Challenges for the $21^{\text {th }}$ Century. NB. EWRA, European Water Resources Association Symposium.

Cek, S., Turan, F. and Atik, E. (2007a). Masculinization of convict cichlid (Cichlasomanigrofasciatum) by immersion in Tribulus terrestris extract. Aquacult. Int., 15:109-119.

Cek, S., Turan, F. and Atik, E. (2007b). The effects of gokshura, Tribulus terrestris, on sex reversal of guppy, Poeciliareticulata. Pakistan J. Biol. Sci., 10:718-725.

Chakraborty, S. B., Horn, P. and Hancz, C. (2013). Application of phytochemicals as growth-promoters and endocrine modulators in fish culture. Rev Aquacul., DOI: 10.1111/raq.12021.

Contreras-Sanchez, W.M., Fitzpatrick, M.S. and Schreck, C.B. (2001). Fate of methyl testosterone in the pond environment: detection of MT in pond soil from a CRSPsite. In: Eighteenth annual technical report. Gupta A, McElwee K, Burke D, Burright J, Cummings X, Egna H (Eds) Oregon State university, Corvallis, Oregon, PP: 79-82.

El-Desoky,G.E., Ragab, A.A., Ismail, S.A. and Kamal, A.E. (1995). Effect of palm-pollen grains (phoenix dactylifera) on sex hormones, proteins, lipids and liver functions. J. Agric. Sci. Mansoura Univ., 20:4249-4268.

El-Sayed, A.M. (2006). Tilapia Culture. CABI Publishing, CABI International Willingford, Oxford shire, United kingdom.

FAO. (2012). The state of world fisheries and aquaculture 2012. FAO, Rome, Italy.

Felix, S. (1989). Effect of 17a-methyl testosterone on the growth of ornamental fish, xiphophorusmaculatus. Indian. J. Fish., 36: 263-265.

Francis, G., Kerem, Z., Makkar, H.P.S. and Becker, K. (2002). The biological action of saponins in animal systems: a review. Br. J. Nutr., 88:587-605.

Ganzera, M., Bedir, E. and Khan, I.A. (2001). Determination of steroidal saponins in Tribulus terrestris by reversed-phase high-performance liquid chromatography and evaporative light scattering detection. J. Pharm. Sci., 90:1752-1758. 
Gauthaman, K., Adaikan, P.G., Prasad, R.N.V., Goh, V.H.H. and Ng, S.C. (2000). Changes in hormonal parameters secondary to intravenous administration of Tribulus terrestris extract in primates. Int. J. Impot. Res., 12: 6.

Gauthaman, K., Adaikan, P.G. and Prasad, R.N. (2002).Aphrodisiac properties of Tribulus terrestris (Protodioscin) in normal and castrated rats. Life Sci., 71:1385-96.

Gauthaman, K. and Adaikan, P.G. (2008). The hormonal effects of Tribulus terrestris and its role in the management of male erectile dysfunction - an evaluation using primates, rabbit and rat. Phytomedicine, 15: 44-54.

Goda, A.M.A.S. (2008). Effect of dietary ginseng herb (Ginsana g115) supplementation on growth, feed utilization, and hematological indices of Nile tilapia, Oreochromis niloticus (L.), Fingerlings. J. World Aquacult. Soc., 39:205-214.

Guerrero, R.D. (1975).Use of androgens for the production of all-male Tilapia aurea (Steindachner). Trans. Am. Fish Soc., 104:342-348.

Guerrero, R.D. and Shelton, W.L. (1974). An aceto-carmine squash method for sexing juvenile fishes. The Progressive Fish-Culturist 36:56-56. doi:[];10.1577/1548-8659(1974)36[56:AASMFS]2.0.CO;2.

Hassan, W.A., El-kashlan, A.M. and Ehssan, N.A. (2012). Egyptian date palm pollen ameliorates testicular dysfunction induced by cadmium chloride in adult male rats. J. American. Sci., 8:659-669.

Huggard, D., Khakoo, Z., Kassam, G. and Habibi, H.R. (1996). Effect of testosterone on growth hormone gene expression in the goldfish pituitary. Can. J. Physiol. Pharmacol., 74(9):1039-1046.

Iftikhar, S., Bashir, A., Anwar, M.S., Mastoi, S.M. and Shahzad, M. (2011). Effect of date palm pollen (DPP) on serum testosterone levels in prepubertal albino rats. Pak. J. Med. Sci., 5:639-645.

Marbeen, M.I., Al-Snafi, A.E., Marbut, M.M. and Allahwerdy, I.Y. (2005). The probable therapeutic effects of date palm pollen in the treatment of male infertility. Tikrit J. Pharmaceut. Sci., 1:30-35.

Mirza, J.A. and Shelton, W.L. (1988). Induction of gynogenesis and sex reversal in silver carp. Aquaculture, 68: 1-14.

Nakari, T. and Erkomaa, K. (2003). Effects of phytosterols on zebrafish reproduction in multigeneration test. Environmental Pollut., 123(2):267273.

Navarro-Martín, L., Blázquez, M. and Piferrer, F. (2009). Masculinization of the European sea bass (Dicentrarchuslabrax) by treatment with an androgen or aromatase inhibitor involves different gene expression and has distinct lasting effects on maturation. Gen. Comp. Endocrinol., 160: 3-11.

Norbeck, L.A. and Sheridan, M.A. (2011). An in vitro model for evaluating peripheral regulation of growth in fish: Effects of $17 \beta$-estradiol and testosterone on the expression of growth hormone receptors, insulin-like growth factors, and insulin-like growth factor type 1 receptors in rainbow trout (Oncorhynchus mykiss). Gen. Comp. Endocrinol., 173: 270-280. 
NRC. (1993). Nutrient requirements of fish. National Academy Press. Washington DC.

Omitoyin, B.O., Ajani, E.K. and Sadiq, H.O. (2013).Preliminary investigation of Tribulus terrestris (Linn., 1753) extracts as natural sex reversal agent in Oreochromis niloticus (Linn., 1758) larvae. Int. J. Aquacult., 3(23):133-137.

Piferrer, F. and Lim, L.C. (1997).Application of sex reversal technology in ornamental fish culture. Aquarium Science \& Conservation, 1:113-118.

Salvati, G., Genovesi, G., Marcellini, L., Paolini, P., De Nuccio, I., Pepe, M. and Re, M. (1996). Effects of Panax ginseng C.A. Meyer saponins on male fertility. Panminerva Medica., 38:249-254.

Tariq-Ezaz, M., Mayers, J.M., Powell, S.F., Mc Andrew, B.J. and Penman, D.J. (2004). Sex ratio in the progeny of androgenic and gynogenetic YY male Nile tilapia, Oreochromis niloticusL., Aquaculture, 232:205-214.

Tsai, S.C., Chiao, Y.C., Lu, C.C. and Wang, P.S. (2003). Stimulation of the secretion of luteinizing hormone by ginsenoside-Rb1 in male rats. Chin. J. Physiol., 46:1-7.

Turan, F. and Cek, S. (2007). Masculinization of African catfish (Clarias gariepinus) treated with Gokshura (Tribulus terrestris). Israeli J. Aquacult Bamidgeh 59(4): 224-229.

Tveiten, H., Mayer, I., Johnsen, H.K. and Jobling, M.(1998). Sex steroids, growth and condition of Arctic charr brood stock during an annual cycle. J. Fish. Biol., 53:714-727.

Velazquez, I. and Alter, B.P. (2004). Androgens and liver tumors: Fanconi's anemia and non-Fanconi's conditions. Am. J. Hematol., 77:257-267.

Wassermann, G.J. and Afonso, L.O.B. (2003). Sex reversal in Nile tilapia Oreochromis niloticus, (Linnaeus) by androgen immersion, Aquacult. Res., 34(1): 65-71.

Yan, L., Meng, Q.W., Lee, J.H., Wang, J.P. and Kim, I.H. (2011). Effects of dietary wild-ginseng adventitious root meal on growth performance, blood profiles, relative organ weight and meat quality in broiler chickens. AsianAust. J. Anim. Sci., 24(2): 258-263.

Yilmaz, E., Çek, Ş. and Mazlum, Y. (2009). The effects of combined phytoestrogen administration on growth performance, sex differentiation and body composition of sharptooth catfish Clarias gariepinus (Burchell, 1822). Turkish J. Fish Aquat.Sci., 9: 33-37. 
الملخص العربي

\title{
تأثير التغذية بالفيتوكيميكال الطبيعية علي التحول الجنسي الأكري ومعدلات النمو والاستفادة من الغذاء ومكونات الجسم ليرقات البلطي النيلي
}

\author{
إجلال علي عمر ${ }^{1}{ }^{1}$ \\ 1 قسم الإنتاج الحيواني والسمكي - كليه الزراعة (سابا باشا) - جامعه الأسكندريه مصر • \\ 2 قسم الدراسات البيئية - معهد الدراسات العليا والبحوث - جامعه الأسكندريه - مصر .
}

تهدف الدراسة إلي تقييم استخدام الفيتوكيميكال الطبيعية كمصدر بديل لإحداث التحول الجنسي الذكري بالمقارنة بهرمون التستوستيرون 17a-methyl testosterone. تمت معاملة زريعة البلطي حديثه الفقس بهرمون التستوستيرون مقارنه بمستخلص الجنسنج بتركيز 0.2 و0.4 جم/كجم علف وبمستخلص نبات القطب (الحسك) بتركيز 0.6 و 1.6 جم/كجم علف وبطلع النخيل بتركيز 3 و6 جم/كجم علف. استمرت التغذية بالعلف المعامل بهرمون

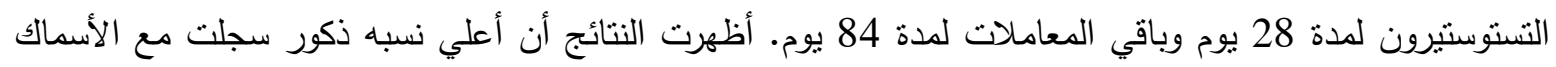
المعاملة بهرمون التستوستيرون (92.3\%) تبعها الزريعه المعاملة بمستخلص نبات القطب بتركيز 1.2 جم/كجم علف بـ (464.48\%) ثم تركيز 0.6 جم/كجم علف (57.76\%) ثم طلع النخيل بتركيز 6 جم/كجم علف (56.67\%)، بينما كانت نسبه الذكور في الأسماك غير المعامله (48.36\%). جميع المعاملات أظهرت معدلات إعاشة طبيعيه علي مدار فترة التجربة والذي يثبت أن هذه الإضافات غير سامه علي الأسماك. كما أن الأسماك المعاملة بالفيتوكيميكال أظهرت ارتفاع معدلات النمو ومعدل التحول الغذائي بالمقارنة بالغير معامله وخصوصاً مع الأسماك المعاملة

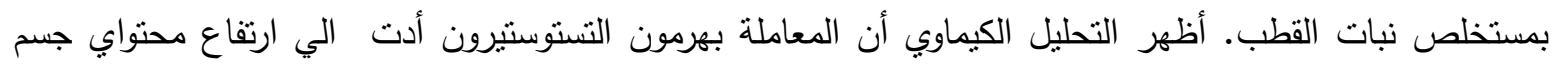
الأسماك من الرطوبة وانخفاض محتواها من الدهون معنوياً بالمقارنة بالمعاملات الأخرى، في حين أن الأسماك المعاملة بالفيتوكيميكال أظهرت تحسن طفيف في محتوي جسم الأسماك من البروتين والدهون بالمقارنة بالأسماك غير الدئ المعاملة.

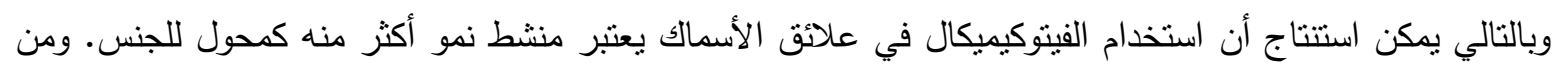
ثم فإنه يوصي باستخدام مستخلص نبات القطب في علائق زريعه البلطي لتأثثره الإيجابي علي النمو . 